\title{
CODIUM AMPHIBIUM: A SPECIES OF DOUBTFUL VALIDITY
}

\author{
By P. C. Silva and D. E. G. Irvine \\ Department of Botany, University of Illinois, Urbana
}

(Text-figs. I-3)

Codium amphibium was described by Harvey (1844) on the basis of material sent to him by David Moore, who in turn had received it from the collector, William M'Calla. This material was said to grow 'on turfy banks at extreme high-water mark, near Roundstone, county Galway', and was described as comprising numerous erect, small (to $\frac{1}{4}$ in. high), simple, cylindrical or subclavate, obtuse fronds arising from a mass of entangled, divaricately branched filaments densely aggregated into widely spreading patches. Harvey's illustration clearly shows the habit, but his drawing of utricles is neither diagnostic nor accurate [as judged from our study of the type material]. Harvey made particular note of the habitat, which he inferred would place the plant 'beyond the reach of the ordinary sea-level'. In a later work, Harvey (1846, pl. 35 B) illustrated this species with similar drawings and added nothing to the description except to extend the maximum height of the fronds to 'nearly half an inch'. Still later, Harvey (I849, p. I94) increased the maximum height of the fronds to an inch, modified 'simple' to 'usually simple, rarely emarginate or forked', added the locality 'at the head of Birtirbui Bay, Galway' and changed the habitat as follows: 'Turf banks, near high-water mark, but washed by every tide...' Kützing (1849, p. 502) furnished a description similar to the original one, based on an Irish specimen sent to him by Berkeley, probably topotype material*. In his illustration of this material, Kützing (1856, pl. 96, fig. á) showed an important character of the utricles: a tendency towards pointed apices.

The first report of C. amphibium from some locality other than Ireland was that of Tellam (I883), who collected what he considered to be this species at Falmouth in 1882 , growing on a small ledge of rocks near high-water mark to the west of Pendennis Castle, sheltered by higher rocks on the south, but covered by every tide. The fronds were said to be $\frac{1}{4}-\frac{3}{8} \mathrm{in}$. high, arising from patches of glossy, dark green filaments which spread through and on the muddy sand covering the rocky ledge. J. Agardh (I887), in his monograph of Codium, placed C. amphibium in his tribus Codii tomentosi. Holmes \& Batters

* The three specimens of $C$. amphibium in Kützing's herbarium at Leiden are labelled 'Roundstone Bay', 'Ireland. Harvey. Herb. Kützing' and 'Connemara. Andrews,' respectively. 
(I890, p. 77) reduced C. amphibium to the status of a form of C. adhaerens. Batters (1902, p.22) listed the Isle of Man as an additional locality for $C$. amphibium on the basis of material from Perwick Bay collected by George in I890. Cotton (19I2, p. II3) reported finding this species on a ledge at the mouth of a cave on Clare Island in 1909 and I9II. He also reported that a special search for the plant at Roundstone during September I9I I was without success. Schmidt (1923) included C. amphibium in his monograph of the genus solely on the basis of previously published accounts, but in 1939, after having had the opportunity to study material from Port-en-Bassin [Calvados, France, reported earlier by Fortin (1935) as an unnamed variety of $C$. tomentosum] in addition to topotype material from Roundstone, he published a supplementary account of the species. The following secondary references complete the literature for C. amphibium: Cocks (1853, p. 77); Gifford (1853, p. 289); Harvey (1857, p. 159, pl. 62, fig. 289); Johnstone \& Croall (1860, p. 5); Gatty (1863, p. I23); Gray (1867, p. 243); DeToni (1889, p. 49I); Knight \& Parke (193I, p. 55); Newton (193I, p. I05); Parke (1953, p. 500).

The amount of information available about C. amphibium is not commensurate with the number of published accounts. Up to now neither hairs nor gametangia have been observed. During the last few years one of us (Silva) has had an opportunity to study collections assigned to this species in the major herbaria of the world in addition to liquid-preserved material from Falmouth and from St Andrews, kindly provided by Dr M. A. Wilson and Dr Irvine, respectively. The other of us (Irvine) has been keenly interested in the problem of C. amphibium because plants suggestive of this species were growing in tide pools that were the object of an ecological study.

An examination of the type collection in Trinity College, Dublin, confirmed the presence of pointed utricles (Fig. I, A), as shown first by Kützing (I856) and later by Schmidt (1939). Juvenile plants of $C$. fragile subsp. atlanticum (Cotton) Silva are immediately called to mind, and it may be noted that a similar impression was gained by W. A. Setchell from his study of topotype collections of C. amphibium. In a letter to A. D. Cotton, dated Io June I930, Setchell wrote, 'In all probability this species is simply a depauperate form of your variety [C. mucronatum var. atlanticum]'. In agreement with the type collection are all topotype collections that we have examined (Fig. I, B) as well as the Cotton specimens from Clare Island (Fig. I, C), the George specimens from the Isle of Man (Fig. I, D), and a collection from Tellam's site near Falmouth (M. A. Wilson, viii.1943; Fig. 2, D).

An opportunity to learn more about C. amphibium was provided by the discovery by Dr Helen Blackler at St Andrews of plants referable to this species growing on the vertical sides and the bottom of a few rock pools on the Hind Rock and a neighbouring ridge at M.H.W.N.T. towards M.H.W.S.T. They were first observed in November 1949 and subsequently have been followed 


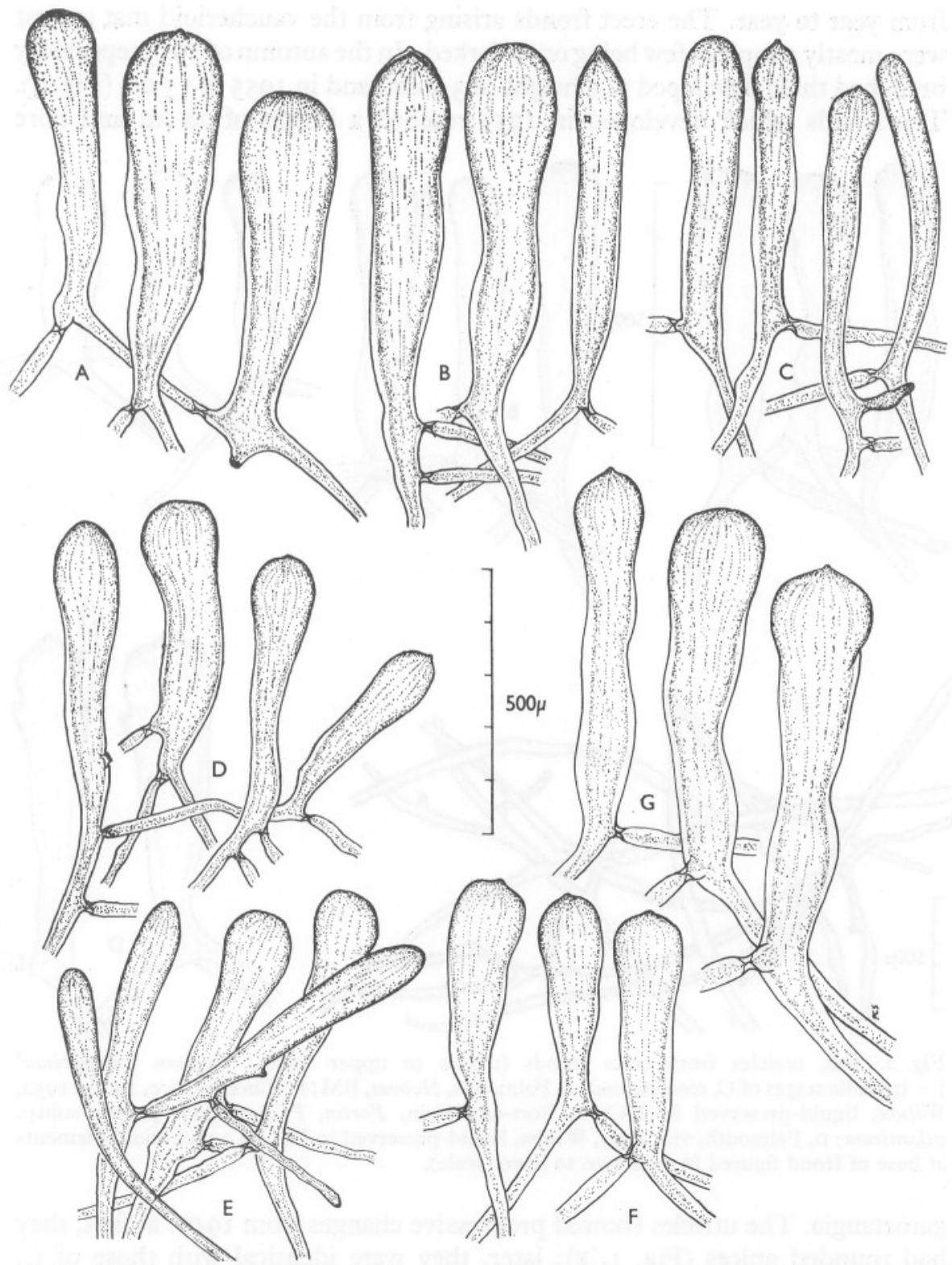

Fig. I. Utricles from erect fronds (samples taken about $3 \mathrm{~mm}$ below tip). A-D, Codium amphibium. A, Roundstone Bay, M'Calla, TCD = type; B, Connemara, M'Calla, K; C, Portlea, Clare Island, viii. I9I1, Cotton 358, K; D, Perwick Bay, Isle of Man, 3. ix. I890, George, BM. E-G, Codium fragile subsp. atlanticum. E, St Andrews, 18. ix. 1952, Irvine, liquid-preserved in UC, frond $5 \mathrm{~mm}$ high; F, St Andrews, xi. 1955, Blackler, UC, frond $4 \mathrm{~mm}$ high; G, St Andrew, 5. x. I955, Blackler, UC, frond $14 \mathrm{~cm}$ high. 
from year to year. The erect fronds arising from the vaucherioid mat at first were mostly simple, a few being once-forked. In the autumn of 1953 repeatedly branched thalli developed to a height of $3.5 \mathrm{~cm}$, and in 1955 to $15 \mathrm{~cm}$ (Fig. 3). The fronds which developed in 1959 reached a height of $28 \mathrm{~cm}$ and bore
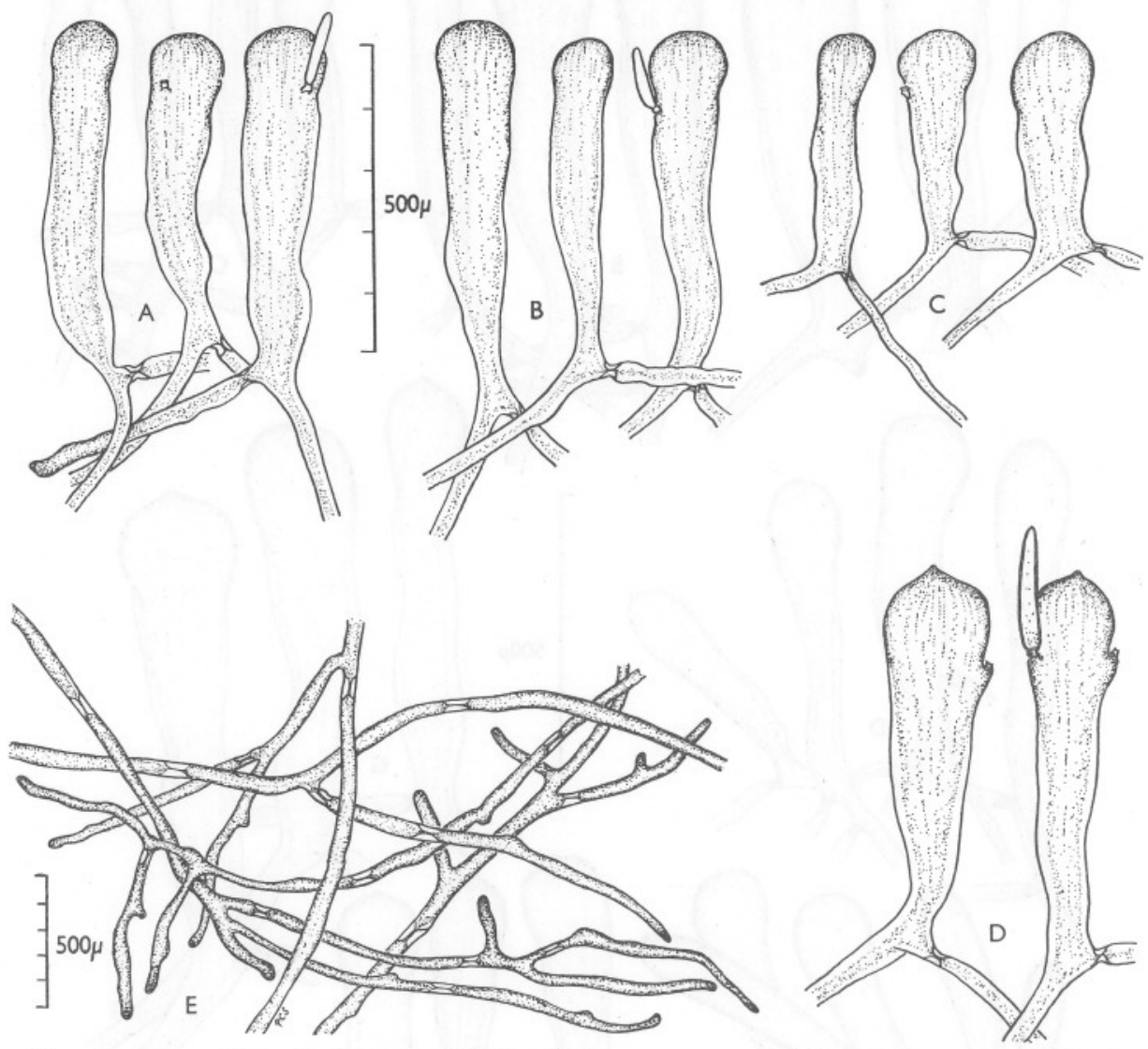

Fig. 2. A-D, utricles from erect fronds (drawn to upper scale). Codium 'amphibium' [= juvenile stages of C. tomentosum]: A, Falmouth, Holmes, BM; B, Elberry Cove, I4. ix. I954, Wilson, liquid-preserved in UC; c, Port-en-Bassin, Fortin, PC. Codium fragile subsp. atlanticum: D, Falmouth, viii. 1943, Wilson, liquid-preserved in UC. E, vaucherioid filaments at base of frond figured in D (drawn to lower scale).

gametangia. The utricles showed progressive changes from 1949: at first, they had rounded apices (Fig. I, E); later, they were identical with those of $C$. fragile subsp. atlanticum (Figs. I, F and $\mathrm{G}$ ). The conclusion is drawn that $C$. amphibium at St Andrews is merely a juvenile stage of $C$. fragile subsp. atlanticum. Blackler (I956), in collaboration with us, reached the same conclusion. It seems reasonable to suppose that the Irish $C$. amphibium has a similar status, although in the absence of direct proof it must be admitted that 
it could be a non-sexually reproducing series of populations maintained in a juvenile stage by the operation of environmental factors related to the purported amphibious habitat.

The development of extensive mossy vaucherioid growths of unconsolidated filaments (Fig. 2, E) is characteristic of members of the Codiaceae (Taylor, Joly \& Bernatowicz, I953). In Codium they represent juvenile stages, although not all species, nor all plants of a given species, seem to develop in this manner. Many fronds apparently arise from a spongy crustose base rather

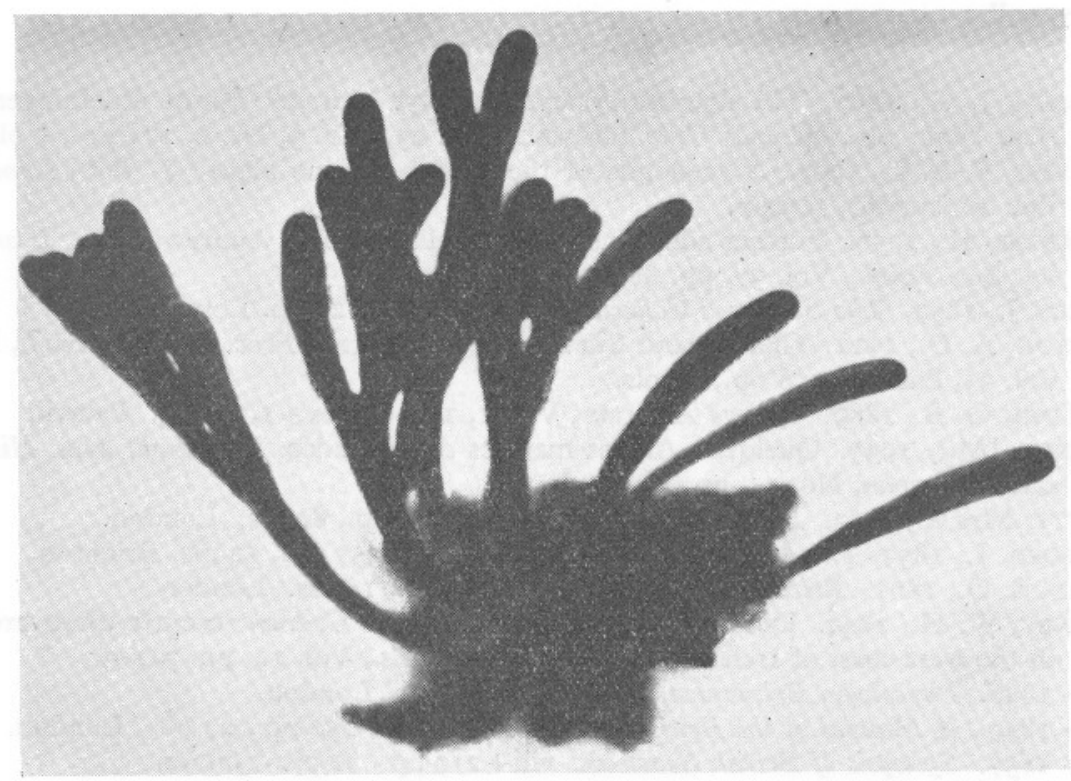

Fig. 3. Codium fragile subsp. atlanticum, St. Andrews, 1957. Photo: Dr Helen Blackler.

than from a vaucherioid mat, although it is possible that in these instances earlier vaucherioid stages have been overlooked. Morphogenesis in Codium has scarcely been studied and holds much promise for future investigation.

A study of some other material agreeing in habit with C. amphibium has revealed that $C$. tomentosum also has a vaucherioid juvenile stage. Several collections from Falmouth by Tellam and by Holmes (Fig. 2, A), the one by Fortin from Port-en-Bassin (Fig. 2, C), and one by Dr M. A. Wilson from Elberry Cove, Torbay, Devon (Fig. 2, B) are all referable to C. tomentosum.

We are grateful to the directors and curators of the following herbaria for the opportunity to study critical specimens: British Museum (Natural History) (BM); Royal Botanic Gardens, Kew (K); Muséum National 
d'Histoire Naturelle, Laboratoire de Cryptogamie, Paris (PC); Trinity College, Dublin (TCD). We wish to thank Dr M. A. Wilson, Dr Mary Parke, and Dr Helen Blackler for their interest and valuable help in this study.

\section{SUMMARY}

Plants agreeing in habit with the material originally described as Codium amphibium have been shown to be juvenile stages of $C$. fragile subsp. atlanticum and $C$. tomentosum. The type specimen is probably a juvenile of the former species. C. fragile subsp. atlanticum is reported for the first time from Cornwall.

\section{REFERENCES}

AgARDH, J. G., I887. Till algernes systematik. Nya bidrag. (Femte afdelningen.) Acta Univ. lund. [Lunds Univ. Aarsskr.], Bd. 23, Afd. 3, Nr. 2, I74 pp., 5 pls.

BAtTers, E. A. L., I902. A catalogue of the British marine algae. F. Bot., Lond., Vol. 40 (suppl.), $107 \mathrm{pp}$.

BLACKLER, H., I956. Further additions to the algal flora of St Andrews, Fife. Trans. bot. Soc. Edinb., Vol. 37, pp. 46-6o.

Cocks, J., I853. The Sea-weed Collector's Guide. xvii +120 pp. London.

Cotron, A. D., I912. Clare Island Survey. Marine algae. Proc. R. Irish Acad., B, Vol. 3I, Part I5, 178 pp., i I pls.

DeToni, G. B., I889. Sylloge Algarum, Vol. I, I2 + cxxxix + I,315 pp. Patavii.

Fortin, [M.], 1935. Quelques Algues marines du Calvados. Bull. Lab. Mus. Hist. nat. St-Servan, No. 14, pp. 14-15.

Gatty, Mrs A., 1863. British Sea-weeds. xlviii + 166 pp., 80 pls. London.

GIFFord, I., I853. The Marine Botanist, 3rd ed. xl+357 pp., I2 pls. Brighton.

Gray, S. O., I867. British Sea-weeds. xxiii +312 pp., I6 pls. London.

HARvey, W. H., 1844. Description of a new species of Codium recently discovered on the west coast of Ireland. Ann. Mag. nat. Hist., Vol. 13, pp. 32 I-3.

I846. Phycologia Britannica, Part 6, pls. 31-36. London.

- 1849. A Manual of the British Marine Algae. lii +252 pp., 27 pls. London. I857. Synopsis of British Seaweeds. viii +219 pp., 80 pls. London.

Holmes, E. M. \& Batters, E. A. L., I890. A revised list of the British marine algae. Ann. Bot., Lond., Vol. 5, pp. 63-107.

Johnstone, W. G. \& Croall, A., 1860. The Nature-printed British Sea-weeds, Vol. $4, x v+324$ pp., pls. I83-207. London.

Knight, M. \& PARKe, M. W., I93I. Manx Algae. I55 pp., I9 pls. Liverpool.

KütZING, F. T., 1849. Species Algarum. vi 922 pp. Lipsiae.

I856. Tabulae Phycologicae, Bd. 6, iv +35 pp., Ioo pls. Nordhausen.

Newton, L., I931. A Handbook of the British Seaweeds. 478 pp. London.

PARKE, M., I953. A preliminary check-list of British marine algae. F. mar. biol. Ass. U.K., Vol. 32, pp. 497-520.

SchмIDT, O. C., I923. Beiträge zur Kenntnis der Gattung Codium Stackh. Bibl. bot., Stuttgart, Heft 9I, 68 pp.

1939. UUber Codium amphibium Moore. Hedwigia, Bd. 78, pp. 268-272.

TAYLOR, W. R., Joly, A. B. \& Bernatowicz, A. J., I953. The relation of Dichotomosiphon pusillus to the algal genus Boodleopsis. Pap. Mich. Acad. Sci., Vol. 38, pp. 97-107.

Tellam, R. V., 1883. [The discovery of a new English marine alga at Falmouth]. Trans. Penzance nat. Hist. Soc., N.S., Vol. I, pp. 296-7. 